\title{
Diet Quality Affects Allergic Peritonitis in Mice
}

\author{
Magdalena CHADZINSKA, Beata BRONIEK and Jacek RADWAN
}

Accepted October 05, 2010

\begin{abstract}
Chadzinska M., Broniek B., RAdwAn J. 2011. Diet quality affects allergic peritonitis in mice. Folia biologica (Kraków) 59: 7-11.

Reasons for the increased prevalence of allergies observed in recent decades remain elusive. Here, we used a murine model to investigate the effect of nutrition on ovalbumin-induced allergic peritonitis. Compared to the organs of mice kept on a standard diet, mice exposed to a low quality diet during the growth period showed a decrease in the mass of metabolic (liver and heart) and, to a much larger extent, in lymphatic (thymus and spleen) organs, but not in testes or intestine mass. Moreover, diet manipulation affected the number of polymorphonuclear granulocytes as well as mast cell number and /or their responsiveness. During allergic peritonitis, mast cells from animals kept on the standard diet reacted to an allergen with degranulation, while the reaction in mice kept on the low quality diet was significantly weaker. However, the immunomodulators of this process remain unidentified as diet quality affected neither anti-ovalbumin IgE level nor synthesis/release of anti-inflammatory IL-10. Further work is needed to identify underlying immunomodulators.

Key words: Allergy, hygiene hypothesis, condition-dependence, polymorphonuclear granulocytes, mast cells, IgE, IL-10.

Magdalena CHADZINSKA, Department of Evolutionary Immunobiology, Institute of Zoology, Jagiellonian University, R. Ingardena 6, 30-060 Kraków, Poland.

Beata BRONIEK, Jacek RADWAN, Molecular and Behavioural Ecology Group, Institute of Environmental Sciences, Jagiellonian University, Gronostajowa 7, 30-387 Kraków, Poland. E-mail: jacek.radwan@uj.edu.pl
\end{abstract}

The prevalence of allergies in developed countries has increased considerably over the last half century. The reasons for this increase remain elusive because changes in human environment over this period include many factors simultaneously (e.g. hygiene, nutrition, allergen exposure, vaccinations, pollution) (CHANG \& PAN 2008). The hygiene hypothesis, originally derived from the observation that hay fever was negatively correlated to the number of siblings (STRACHAN 1989) has received most attention in recent years. Dr. Strachan proposed that increased infection in early childhood due to unhygienic contact with siblings might prevent sensitization to allergens. Many epidemiological studies have since been carried out, revealing patterns that are overall consistent with this hypothesis, although several studies did not find the predicted relationships (reviewed in VON MUTIUS 2007). The mechanistic basis for suppression of allergic sensitization by microorganisms is not fully understood (reviewed in ROMAGNANI 2004). One explanation assumes that reduced exposure to microorganisms in a hygienic environment changes the balance between Th1 and Th2 type cells in favour of the latter, promoting the immune response profile associated with allergies. A more recent alternative (not necessarily mutually exclusive) poses that reduced activation of Treg cells, caused by insufficient stimulation of the immune system, results in reduced immune suppression and consequently overreaction to allergens (YAZDANBAKHSH et al. 2002). The suppressive effect of microorganisms is usually mediated by decreased sensitization, demonstrated by decreased anti-allergen IgE levels (BLUMER et al. 2005). Alternative suppressive effects seem to be associated with helminth infections. The diminished prevalence of allergic responses in a helminth-infected population is associated with a substantial increase in the concentration of polyclonal IgE, which likely saturates mast cell receptors and blocks the binding of specific IgE antibodies, thus inhibiting degranulation and immediate hypersensitivity (LYNCH et al. 1987). Moreover, helminth infections are associated with increased levels of antiinflammatory interleukin-10 (KING et al. 1996).

Another potential factor affecting the propensity of allergies is nutrition. Immune response is likely to be costly, such that only individuals in good condition are capable of bearing this cost (VON SCHANTZ et al. 1999). Poor nutrition has been shown to have evident effects upon immunity and 
resistance to disease (CHANDRA 2002). Malnutrition induces the reduction of inflammatory responses, including decreases of pro-inflammatory (ANSTEAD et al. 2003) and increases of antiinflammatory cytokines (HILLYER et al. 2006).

Here, we manipulate the quality of the diet of $\mathrm{Balb} / \mathrm{c}$ mice that are predisposed to have a strong IgE antibody response (DEARMAN et al. 2003). After the mice reached maturity, they were sensitized with ovalbumin. We then determined how the immune parameters involved in the allergic response (mast cell degranulation, number of polymorphonuclear granulocytes, IgE and IL-10 levels) changed upon a re-challenge with ovalbumin. We expected that the immediate response to ovalbumin would be weaker in poorly nourished mice and that such an effect could be mediated by either a lower anti-ovalbumin IgE level or by a higher level of anti-inflammatory IL-10.

\section{Material and Methods}

\section{Animals}

Forty-two male Balb/c mice (6 weeks old, 21-25 g), purchased from the Institute of Occupational Health, Łódź, Poland, were housed individually in plastic cages at room temperature $\left(20 \pm 2^{\circ} \mathrm{C}\right)$ with a $12 \mathrm{~h}: 12 \mathrm{~h}$ light/dark cycle. During the first week, all mice were fed ad libitum a standard rodent chow (Labofeed Poland, 24\% protein, 3\% fat, $4 \%$ fibre). Water was available ad libitum. During the second week, mice were divided randomly into two diet groups. Mice on the standard diet (SD) continued to be fed the standard chow, whereas the low quality diet group (LD) received pellets produced from the same standard chow diluted with $25 \%$ plant cellulose (Justfiber BFC40, International Fiber Europe, NV, Belgium). The pellets were produced by homogenising the Labofeed diet with cellulose with a mill and then forming pellets after adding some water. The pellets were then dried in an incubator at $40^{\circ} \mathrm{C}$. The diet treatments were maintained for seven weeks. Body mass was measured every 5 days with an accuracy of $0.01 \mathrm{~g}$. At the end of the $8^{\text {th }}$ week, 5 mice reared on SD remained unstimulated (intact, naive), while the rest of the animals (from both SD and LD groups) were sensitized with ovalbumin (OVA), as described below.
OVA sensitization and challenge procedure

Animals were i.p. injected with $125 \mu \mathrm{g}$ OVA adsorbed on $2 \mathrm{mg} \mathrm{Al}(\mathrm{OH})_{3}$ (both Sigma, Germany) in sterile saline $(0.5 \mathrm{ml} / 25 \mathrm{~g}$ b.w.) on days 1 and 8 . On day 15 , the mice were either re-challenged with $5 \mu \mathrm{g} / \mathrm{ml}$ OVA in saline (experimental groups: SD-E, LD-E) or left untreated (control groups: SD-C, LD-C). All animals were decapitated 18 hours later. Blood was collected and centrifuged $(2500 \mathrm{rpm}$, $20 \mathrm{~min})$. Plasma was stored $\left(-20^{\circ} \mathrm{C}\right)$ for IgE level quantification. Peritoneal cavities were lavaged with $1 \mathrm{ml}$ of saline. Aliquots of the lavage fluid were then stained with Turk's solution $(0.01 \%$ crystal violet in 3\% acetic acid), and differential cell counts were performed using a Burker hemocytometer (KOLACZKOWSKA et al. 2001; AJUEBOR et al. 1999). Polymorphonuclear granulocytes (neutrophils and eosinophils), mononuclear cells (monocytes/macrophages and lymphocytes) and mast cells were counted in a haemocytometer. Peritoneal exudate was centrifuged ( $15 \mathrm{~min}, 1500 \mathrm{rpm}$ ) and supernatants were stored $\left(-20^{\circ} \mathrm{C}\right)$ for IL-10 detection.

\section{Morphometrics}

The lymphatic organs (thymus, spleen) and metabolically active organs (small intestine, liver, heart) (KONARZEWSKI \& DIAMOND 1995) and testes were excised after removing adherent fat. Freshly excised organs were weighed with an accuracy of $0.001 \mathrm{~g}$.

\section{Quantification of plasma IgE}

Anti-OVA specific antibodies were measured in plasma samples by ELISA, as previously described (CHANG et al. 2004).

\section{Detection of IL-10 level in peritoneal fluid}

IL-10 levels were estimated by ELISA, according to manufacturer's instructions (BioSource, Cammarillo, USA).

\section{Statistics}

The data were analysed with Statistica ${ }^{\circledR}$. We used analysis of covariance to analyse normally distributed continuous variables and generalized linear models with log link function to analyse Poisson-distributed counts. Diet and injection on day 15 were used as factors for all analyses. Mass 
Table 1

Mass (g) of body and internal organs of mice reared on different diets

\begin{tabular}{||l|c|c|c|c|c||}
\hline \multirow{2}{*}{\multicolumn{1}{|c|}{ Variable }} & \multicolumn{2}{|c|}{ Standard diet (SD) } & \multicolumn{2}{c||}{ Low quality diet (LD) } & \multirow{2}{*}{ P } \\
\cline { 2 - 5 } & Mean & SE & Mean & SE & $<0.001$ \\
\hline \hline Body mass at injection $(\mathrm{n}=42)$ & 29.40500 & 0.512371 & 26.28050 & 0.537379 & $<0.001$ \\
\hline Liver $(\mathrm{n}=42)$ & 1.789682 & 0.033067 & 1.197600 & 0.034681 & 0.001 \\
\hline Heart $(\mathrm{n}=42)$ & 0.152227 & 0.003377 & 0.123625 & 0.003542 & 0.597 \\
\hline Testes $(\mathrm{n}=42)$ & 0.218545 & 0.041859 & 0.268850 & 0.043902 & 0.073 \\
\hline Intestine $(\mathrm{n}=10)$ & 2.930000 & 0.160806 & 3.220000 & 0.131297 & $<0.001$ \\
\hline Thymus $(\mathrm{n}=42)$ & 0.035936 & 0.001592 & 0.012750 & 0.001670 & $<0.001$ \\
\hline Spleen $(\mathrm{n}=42)$ & 0.123364 & 0.003780 & 0.062000 & 0.003965 & $<$ \\
\hline
\end{tabular}

$\mathrm{P}$ values derived from ANCOVA, with body mass at the day of injection as a covariate.

of internal organs was only measured post mortem, therefore only effect of diet was used as a factor. Mass at day 15 was used as a continuous predictor in all analyses. IL-10 and IgE concentrations were reciprocally transformed to achieve normality of distribution.

\section{Results}

Diet manipulation significantly affected body mass and the size of internal organs (Table 1). Mice reared on LD had decreased body mass and smaller livers, hearts and immune organs. In contrast, intestinal mass tended to be higher in the LD group, while the mass of the testes did not differ between diets. The level of IgE in intact (naive, unstimulated) mice was significantly lower than that of the double-challenged mice reared on the same

Table 2

Levels of IgE and interleukin-10 in mice reared on different diets. Mice were exposed to a standard (SD) or low quality diet (LD) and two (control, C) or three times (E) injected with ovalbumin or kept untreated (naive)

\begin{tabular}{||c|c|c|c|c||}
\hline \multirow{2}{*}{ Group } & \multicolumn{2}{|c|}{$\operatorname{IgE}(\mathrm{OD})$} & \multicolumn{2}{c||}{ IL-10 $(\mathrm{pg} / \mathrm{ml})$} \\
\cline { 2 - 5 } & Mean & SE & Mean & SE \\
\hline \hline SD-E $(\mathrm{n}=13)$ & 0.6310 & 0.0677 & 20.58 & 2.14 \\
\hline LD-E $(\mathrm{n}=11)$ & 0.8228 & 0.0736 & 12.95 & 2.33 \\
\hline SD-C $(\mathrm{n}=9)$ & 0.6966 & 0.0814 & 22.01 & 2.59 \\
\hline LD-C $(\mathrm{n}=9)$ & 0.7668 & 0.0814 & 16.62 & 2.59 \\
\hline SD-naive $(\mathrm{n}=5)$ & 0.1870 & 0.023 & 16.06 & 4.23 \\
\hline
\end{tabular}

diet-SD-C (Table 2) confirming the effectiveness of our sensitization procedure $(\mathrm{t}$ test with separate variances, $\mathrm{t}=5.81, \mathrm{df}=4.20, \mathrm{P}=0.004)$. The average number of full mast cells in intact mice was $5.24 \pm 1.14\left(\times 10^{4} /\right.$ per cavity $)$ compared to $7.22 \pm 1.89$ ( $\times 10^{4} /$ per cavity) for double-challenged mice reared on the standard diet - SD-C (MannWhitney $\mathrm{U}=21, \mathrm{n}_{1}=9, \mathrm{n}_{2}=4$, n.s.). Polymorphonuclear granulocytes were absent in the peritoneal cavity of intact mice and their number increased after OVA treatment to $8.77 \pm 3.65\left(\times 10^{6} /\right.$ per cavity) in SD-C mice.

We have found a significant relationship between diet and re-challenge (the third OVA injection on day 15), with respect to the number of full (non-degranulated) mast cells (Fig. 1A; loglikelihood $\chi^{2}=11.06, \mathrm{df}=1, \mathrm{P}=0.001$ ). The number of full mast cells decreased after the third OVA injection for mice reared on standard diet: SD-E $\left(\log\right.$-likelihood $\left.\chi^{2}=5.27, \mathrm{df}=1, \mathrm{P}=0.020\right)$ but remained unchanged for diet-restricted mice: LD-E $\left(\log\right.$-likelihood $\left.\chi^{2}=0.45, \mathrm{df}=1, \mathrm{P}=0.502\right)$.

There was a significant interaction between diet and re-challenge in their effect on the number of polymorphonuclear granulocytes detected (loglikelihood $\chi^{2}=5.81, \mathrm{df}=1, \mathrm{P}=0.015$ ). There was also a significant main effect of re-challenge $\left(\chi^{2}=19.01, \mathrm{df}=1, \mathrm{P} .001\right)$. The interaction was mainly due to the lower number of polymorphonuclear granulocytes in double-challenged LD-C mice compared to SD-C mice (log-likelihood $\left.\chi^{2}=5.07, \mathrm{df}=1, \mathrm{P}=0.024\right)$. In the case of rechallenged mice (SD-E vs. LD-E) the mean polymorphonuclear granulocyte counts were similar $\left(\chi^{2}=1.43, \mathrm{df}=1, \mathrm{P}=0.230\right)$; the differences in number of cells migrating to the peritoneum after 

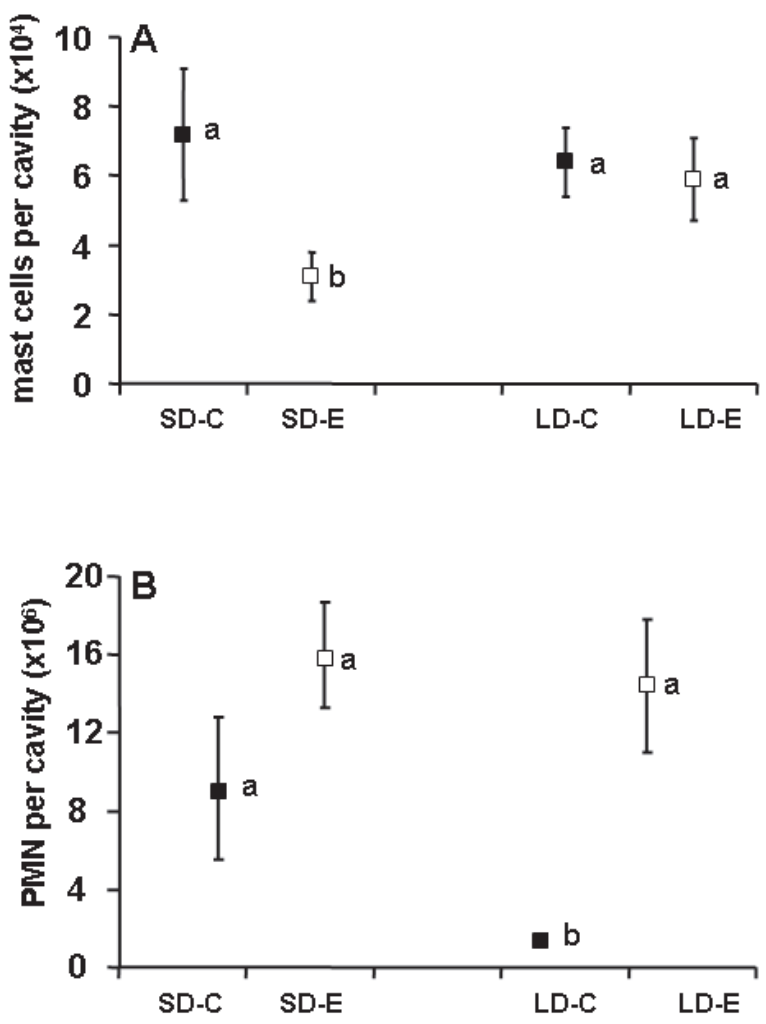

Fig. 1. The number of non-degranulated peritoneal mast cells $(\mathrm{A})$ and polymorphonuclear granulocytes (PMN, B) in the peritoneal cavity. Mice were exposed to a standard (SD) or low quality diet (LD) and two (control, C) or three times (E) injected with ovalbumin. Means \pm SE. Mean values not sharing letters are significantly different statistically.

the third OVA-injection were thus more pronounced in LD than SD animals, (Fig. 1B).

The number of cells in the remaining fraction of leucocytes (including mononuclear cells) was affected by diet (standard diet, mean $\pm \mathrm{SE}=69.89 \pm 4.94$, low quality diet, $56.20 \pm 5.55$; log-likelihood $\left.\chi^{2}=5.729208, \mathrm{df}=1, \mathrm{P}=0.016\right)$ but not by rechallenge (n.s.) or interaction (n.s.).

Descriptive statistics for the levels of immunomodulators measured are shown in Table 2. Neither diet nor re-challenge significantly affected IgE level. The level of IL-10 was higher in mice reared on a standard diet, but the difference was marginally non-significant $\left(\mathrm{F}_{1,37}=3.49, \mathrm{P}=0.069\right)$.

\section{Discussion}

Changes in diet quality did not affect the mass of the testes, while intestinal mass was lower in SD mice, as commonly observed in rodents reared on fiber-rich diets (KOTEJA 1996). In contrast, the lymphatic organs of mice exposed to a low quality diet showed a decreased mass. In particular, the mass of the thymus was three times lower, and spleen mass was two times lower than in animals reared on the standard diet. A similar effect was observed in the case of liver and heart; however, the differences were much less pronounced (Table 1). Lymphoid tissues are acutely sensitive to undernutrition, and severe malnutrition may lead to "nutritional thymectomy" and depletions of lymphoid cells in the spleen and lymph nodes (CHANDRA 2002). Such processes must affect the peripheral immune response. Indeed, after two OVA injections mice from the LD-C group exhibited a decrease in the number of polymorphonuclear granulocytes and remaining leukocytes in the peritoneal cavity compared with SD-C animals (Fig. 1B). In accordance, experimental short-term dietary restriction impaired leukocyte exudation into local inflammatory sites in murine peritonitis (IKEDA et al. 2001). Diet-induced reduction of peritoneal granulocytes can be connected with imbalanced synthesis/release of pro- and antiinflammatory cytokines. It was shown that peritoneal macrophages from malnourished mice produced a decreased level of nitric oxide and pro-inflammatory TNF- $\alpha$, but not IL-6 (ANSTEAD et al. 2003): the authors concluded that initial deficits in the activity of NF- $\kappa \mathrm{B}$ (a principal proinflammatory transcription factor) in malnourished mice leads to decreased TNF- $\alpha$. Surprisingly, the influx of polymorphonuclear granulocytes was similar in SD-E and LD-E groups after the third OVA-injection in the present experiments.

Most importantly, we showed that dietary manipulation changed mast cell numbers and/or their responsiveness. During allergic peritonitis, mast cells from SD animals reacted to ovalbumin rechallenge by degranulation, while the reaction of the LD group was significantly weaker. This was not due to stronger sensitization of SD animals, as diet quality did not affect IgE levels. The weaker reaction could also have resulted from some form of suppression of inflammatory response in the LD group in which the mast cell count did not differ significantly between re-challenged LD-E and control animals LD-C (Fig. 1A).

Previous data concerning the effects of malnutrition on IgE levels and allergic responses are contradictory. Children with moderate protein deficits have reduced levels of $\operatorname{IgE}$, which corresponds with a reduced atopic reaction (FORTE et al. 2003). In contrast, people in Africa presenting variable degrees of malnutrition have low incidences of allergic diseases despite having high $\operatorname{IgE}$ levels in the serum (GODFREY 1975). This can be associated with high parasitaemia and increased production of non-specific IgE as discussed in the Introduction (LYNCH et al. 1987). In the present experiments, however, the "IgE blocking hypothe- 
sis" can be excluded, as the level of specific antiOVA IgE was measured.

Suppression of allergic inflammatory response was not mediated by IL-10 which, if anything, tended to be found at higher concentrations in animals reared on a standard diet. Thus some other as yet unidentified anti-inflammatory mechanism must be operating in this system.

Summarizing, we found significant negative effects of low quality diet on the size of immune organs and, as predicted, on the number of polymorphonuclear granulocytes and mast cell responsiveness, although neither IgE nor IL-10 seem to have mediated the response. Overall, our data suggest that immunocompetence must compete with other life-history components like growth, thermoregulation, and reproduction for access to limiting resources (energy, protein, nutrients), and that such trade-offs may play a role in modulating the propensity to allergic/inflammatory responses. Further work aimed to find the direct mediators/regulators of this process is thus required.

\section{References}

AJuebor M. N., DAS A. M., VirÁG L., Flower R. J., SZABÓ C., PERRETTI M. 1999. Role of resident peritoneal macrophages and mast cells in chemokine production and neutrophil migration in acute inflammation: evidence for an inhibitory loop involving endogenous IL-10. J. Immunol. 162: $1685-1691$.

Anstead G. M., ChandraseKar B., Zhang Q., Melby P C. 2003. Multinutrient undernutrition dysregulates the resident macrophage proinflammatory cytokine network, nuclear factor-kappaB activation, and nitric oxide production. J. Leukoc. Biol. 74: 982-991.

Blumer N., Herz U., Wegmann M., RenZ H. 2005. Prenatal lipopolysaccharide-exposure prevents allergic sensitization and airway inflammation, but not airway responsiveness in a murine model of experimental asthma. Clin. Exp. Allergy 35: 397-402.

CHANDRA R. K. 2002. Nutrition and the immune system from birth to old age. Eur. J. Clin. Nutr. 56: S73-76.

Chang T. W., PAN A. Y. 2008. Cumulative environmental changes, skewed antigen exposure, and the increase of allergy. Adv. Immunol. 98: 39-83.

CHANG Y. S., Kim Y. K., KIM T. B., KANG H. R., KIM S. S., BAHN J. W., Min K. U., KIM Y. Y., CHO S. H. 2004. Airway inflammation and allergen specific IgE production may per- sist longer than airway hyperresponsiveness in mice. J. Korean Med. Sci. 19: 69-73.

Dearman R. J., Stone S., CAdDick H. T., BASKetter D. A., KIMBER I. 2003. Evaluation of protein allergenic potential in mice: dose-response analyses. Clin. Exp. Allergy 33: 1586-1594.

Forte W. C. , Santos de Menezes M. C., Horta C., CarNEIRO LEAO BACH R. 2003. Serum IgE level in malnutrition. Allergol. Immunopathol. (Madr.) 31: 83-86.

GODFREY R. C. 1975. Asthma and IgE levels in rural and urban communities of the Gambia. Clin. Allergy 5: 201-207.

Hill yer L., Dao B., Niemiec P., Lee S., Doidge M., BeMBEN I., NEYESTANI T., WOODWARD B. 2006. Elevated bioactivity of the tolerogenic cytokines, interleukin-10 and transforming growth factor-beta, in the blood of acutely malnourished weanling mice. Exp. Biol. Med. (Maywood) 231: 1439-1447.

Ikeda S., SAito H., Fukatsu K., InOUE T., HAN I., FuruKawa S., Matsuda T., Hidemura A. 2001. Dietary restriction impairs neutrophil exudation by reducing CD11b/CD18 expression and chemokine production. Arch. Surg. 136: 297-304.

King C. L., Medhat A., Malhotra I., Nafeh M., Helmy A., KHAUDARY J., IBRAHIM S., EL-SHERBINY M., ZAKY S., StUPi R. J., BRUSTOSKI K., Shehata M., SHATA M. T. 1996. Cytokine control of parasite-specific anergy in human urinary schistosomiasis. IL-10 modulates lymphocyte reactivity. J. Immunol. 156: 4715-4721.

KolaczKowsKa E., SELJELID R., Plytycz B. 2001. Role of mast cells in zymosan-induced peritoneal inflammation in Balb/c and mast cell-deficient WBB6F1 mice. J. Leukoc. Biol. 69: 33-42.

KONARZEWSKI M., DiAmOND J. 1995. Evolution of basal metabolic rate and organ masses in laboratory mice. Evolution 49: 1239-1248.

KoteJA P. 1996. Limits to energy budgets in a rodent, /Peromyscus maniculatus/: does gut capacity set the limit. Physiol. Zool. 69: 994-1020.

LYNCH N. R., LOPEZ R. I., DI PRISCO-FUENMAYOR M. C., Hagel I., Medouze L., Viana G., Ortega C., Prato G. 1987. Allergic reactivity and socio-economic level in a tropical environment. Clin. Allergy 17: 199-207.

ROMAGNANI S. 2004. The increased prevalence of allergy and the hygiene hypothesis: missing immune deviation, reduced immune suppression, or both? Immunology 112: 352-363.

STRACHAN D. P. 1989. Hay fever, hygiene, and household size. BMJ. 299: 1259-1260.

VON MUTIUS E. 2007. Allergies, infections and the hygiene hypothesis - the epidemiological evidence. Immunobiology 212: 433-439.

VON SCHANTZ T., BENSCH S., GRAHN M., HASSELQUIST D., WiTTZELL H. 1999. Good genes, oxidative stress and condition-dependent sexual signals. Proc. Biol. Sci. 266: $1-12$.

YAZDANBAKHSH M., KREMSNER P. G., VAN Ree R. 2002. Allergy, parasites, and the hygiene hypothesis. Science 296: 490-494. 